\title{
PENGARUH PENGGUNAAN MEDIA SOSIAL TERHADAP ETIKA PERGAULAN ANTAR LAWAN JENIS DI KALANGAN REMAJA ISLAM (Studi Kasus Pada Remaja Se-Tamantirto Utara)
}

\author{
Anisa Rohmawati \\ Program Pasca Sarjana \\ Program Studi Magister Studi Islam \\ Universitas Muhammadiyah Yogyakarta \\ E-mail: anisa94bantul@gmail.com
}

\begin{abstract}
Abstrak
Penelitian ini bertujuan 1) mendiskripsikan dan menjelaskan mengenai penggunaan media sosial di kalangan remaja Islam Tamantirto Utara, 2) mendiskripsikan dan menjelaskan etika pergaulan antar lawan jenis pada remaja Islam Tamantirto Utara, 3) mengetahui dan menganalisis seberapa besar pengaruh penggunaan media sosial dalam mempengaruhi etika pergaulan antar lawan jenis di kalangan remaja Islam Tamantirto Utara. Jenis penelitian ini yaitu korelasional dengan analisis data berupa statistik deskriptif dan regresi sederhana. Populasi dalam penelitian ini seluruh remaja Islam Tamantirto Utara. Sampel dalam penelitian ini remaja Islam yang berusia 12-20 tahun. Metode pengumpulan data menngunakan angket, wawancara dan dokumentasi. Hasil penelitian ini menunjukkan bahwa pengaruh penggunaan media sosial (R Square) sebesar $6,5 \%$ artinya bahwa pengaruh variabel independen terhadap variabel dependen dikategorikan rendah. Variabel penggunaan media sosial tidak memiliki kaitan dengan etika pergaulan antar lawan jenis. Sehingga nilai pengaruhnya kecil dan 93,5\% sisanya dipengaruhi oleh faktor lain. Nilai signifikan dari hasil analisis regresi sebesar 0,005
\end{abstract}

Kata Kunci: penggunaan media sosial, etika pergaulan antar lawan jenis, remaja Islam

\begin{abstract}
This study aims at 1) describing and explaining the use of social media among Tamantirto North Muslim adolescents, 2) describing and explaining the ethics of association between opposite sex in Tamantirto North Muslim adolescents, 3) knowing and analyzing how much influence social media use in influencing social ethics between the opposite sex among Muslim youth in North Tamantirto. This type of research is correlational with data analysis in the form of descriptive statistics and simple regression. The population in this study were all Tamantirto North Muslim youth. The sample in this study was Islamic adolescents aged 12-20 years. Data collection methods use questionnaires, interviews and documentation. The results of this study indicate that the influence of the use of social media ( $R$ Square) of $6.5 \%$ means that the influence of independent variables on the dependent variable is categorized as low. Variable use of social media has no relation to the ethics of association between the opposite sex. So that the effect is small and the remaining $93.5 \%$ is influenced by other factors. Significant value from the results of the regression analysis is 0.005
\end{abstract}

Keywords: use of social media, social ethics among the opposite sex, Islamic youth

\section{Info Artikel}

Diterima Agustus 2018, disetujui September 2018, diterbitkan Desember 2018

Dipublikasikan Oleh: Program Studi Bimbingan dan Konseling 


\section{PENDAHULUAN}

Masa remaja sebagai masa peralihan dan pertumbuhan dari kanak-kanak menuju ke dewasa yang lebih matang.Pada masa ini remaja akan mengalami perubahan yang begitu besar yang ditandai dengan adanya perubahan biologis, kognitif, sosial-emosional, psikologis, dan pencarian identitas diri. Bahkan remaja akan membentuk suatu hubungan yang baru dengan mengekspresikan perasaan seksual ke lawan jenis. Selain itu, masa remaja sebagai masa di mana seseorang mengalami kebingungan atau persimpangan antara yang diinginkan dengan yang seharusnya dilakukan. Pada masa ini, remaja mulai memiliki minat dengan lawan jenis. Hal ini seperti mulai timbul benih cinta, perhatian, dan perasaan senang terhadap lawan jenis. Bahkan masa remaja merupakan masa ingin tahu, penasaran, dan ingin mencoba hal-hal baru. Hal ini disebabkan karena adanya dorongan nafsu dari diri remaja tersebut untuk melakukan halhal yang baru di luar pengetahuan dan pengawasan orang tua. Sehingga mengakibatkan remaja sekarang ini lebih bebas dalam pergaulan dan bahkan tidak bisa membatasi maupun memilih-milih perilaku yang baik atau buruk ketika bergaul dengan lingkungan di sekitar atau teman sebaya mereka.

Pergaulan merupakan sesuatu kebutuhan yang sangat penting bagi manusia. Karena manusia diciptakan oleh Allah Swt sebagai makluk sosial. Dalam kehidupan sehari-hari, manusia tidak akan terlepas dari interaksi (pergaulan), sosialisasi, dan komunikasi dengan individu lainnya. Bahkan manusia pada dasarnya sangat membutuhkan orang lain dalam memenuhi kebutuhan dan mempertahankan hidupnya. Dengan kata lain manusia tidak bisa hidup sendiri. Sehingga dibutuhkan pergaulan antar manusia dalam kehidupan sehari-hari yang sesuai dengan aturan yang berlaku di lingkungan masyarakat.Dalam bergaul manusia bisa bersifat langsung ataupun tidak langsung.Pergaulan langsung adalah pergaulan yang dilakukan melalui suatu pertemuan dengan bertatap muka dan adanya dialog timbal balik secara langsung dari kedua belah pihak yang bersangkutan tanpa melalui suatu perantara. Dengan kata lain adanya interaksi langsung atau tatap muka di antara kedua belah pihak yang saling mengerti.

Pergaulan tidak langsung adalah pergaulan yang terjadi melalui suatu perantara. Salah satu pergaulan tidak langsung adalah melalui media sosial.Media sosial merupakan suatu situs yang dimiliki oleh setiap individu dan bahkan individu tersebut bisa membuat web page pribadi. Selanjutnya bisa terkoneksi dengan teman-teman atau pengguna lainnya untuk melakukan komunikasi dan berbagi informasi satu sama lain. Bahkan media sosial mengajak setiap 
individu untuk berpartisipasi dalam memberikan komentar, kontribusi, feedback secara terbuka, serta berbagi informasi dengan cepat dan tanpa batas. Adapun media sosial terbesar dan sering dipakai oleh para pengguna seperti facebook, twitter, myspace, instagram, path, line, whatsapp, youtube, blackberry messenger dan sebagainya.

Salah satu pergaulan yang penting untuk diketahui remaja adalah pergaulan antar lawan jenis.Sebab pergaulan remaja di zaman sekarang ini sudah banyak yang melewati batas. Batasan-batasan dalam pergaulan antar lawan jenis sudah tidak diperhatikan atau dihiraukan lagi oleh remaja saat ini. Bahkan remaja sekarang ini terlihat lebih cuek dalam menanggapi masalah tersebut. Padahal di dalam Al-Qur'an, Allah Swt sudah menjelaskan bahwasanya umat Islam dilarang mendekati perbuatan zina. Maksudnya yaitu perbuatan-perbuatan yang dapat mengantarkan manusia ke dalam perbuatan perzinaan. Sebagai contoh adalah pacaran, ciuman, pergaulan bebas antara laki-laki dan perempuan, serta melihat tayangan atau video yang dapat membangkitkan syahwat. Itu semua dapat mengarahkan kepada perbuataan perzinaan.

Hal tersebut didukung dari survei demografi dan kesehatan menunjukkan bahwa remaja usia 15-17 tahun memiliki proporsi yang sangat besar dalam hal berpacaran. Dengan proporsi remaja perempuan sebanyak 33,3\%, sedangkan $34,5 \%$ remaja laki-laki yang berusia 15-19 tahun, sudah berani melakukan pacaran ketika mereka belum genap usia 15 tahun. Usia tersebut memiliki resiko berpacaran yang tidak sehat dan pada akhirnya akan berakibat pada hubungan seks pra nikah. Bahkan hasil survei dari BKKBN menunjukkan bahwa $63 \%$ pelajar SMP dan SMA di Indonesia pernah melakukan hubungan seks diluar nikah. Bahkan sebanyak $21 \%$ pernah melakukan aborsi.

Berdasarkan uraian di atas pergaulan antar lawan jenis di kalangan remaja merupakan sesuatu yang penting untuk dibahas. Sebab pergaulan antar lawan jenis remaja saat ini sudah sangat memprihatinkan. Di lingkungan sekitarnya remaja kurang memahami adab dalam pergaulan dengan lawan jenis. Padahal remaja merupakan generasi penerus bangsa dan pemimpin bangsa yang akan mendatang. Oleh karena itu penelitian ini penting untuk dilakukan. Peneliti akan melakukan penelitian mengenai penggunaan media sosial terhadap etika pergaulan antar lawan jenis di kalangan remaja Islam.

\section{Remaja}

Remaja dikenal dengan "adolescence", adapun bahasa Latinnya berasal dari kata "adolescere" (kata benda adolescentia atau remaja), maka dapat diartikan sebagai perkembangan menuju ke tahap selanjutnya (dewasa). Istilah adolescence memiliki arti luas, yang 
meliputi kematangan fisik, mental, emosional, dan sosial remaja tersebut. Pendapat tersebut telah dibahas oleh Piaget bahwa masa remaja merupakan masa yang mana individu dapat berintegrasi dengan masyarakat di sekitarnya. Sedangkan, Papalia mengungkapkan bahwa usia remaja dimulai sekitar usia 11 atau 12 tahun sampai di awal usia dua puluhan. Masa tersebut akan membawa perubahan yang besar dalam semua ranah perkembangan. Monks, Knoers dan Haditono (2001) membagi usia remaja ke dalam empat tahap yakni masa pra-pubertas (10-12 tahun), masa pubertas (12-15 tahun), masa remaja pertengahan (15-18 tahun) dan masa remaja akhir (18-21 tahun). Masa awal sampai akhir pada remaja disebut dengan masa adolesen. Hal ini senada dengan Smetana yang mengungkapkan bahwa "most researchers have pased adolescence into three development periods, entailing adolescence (typically ages 10-13), middle adolescence (ages 1417), and late adolescence (18 until the early twenties)".

Masa transisi dari kanak-kanak ke dewasa merupakan definsi dari masa remaja. Di mana rentang usia remaja sekitar 10 sampai 20 tahun, yang dilalui oleh setiap individu sebelum individu tersebut menjadi dewasa yang matang, bertanggung jawab, bermoral, beretika, dan kreatif. Serta ditandai dengan perubahan biologis, psikologis, kognitif, dan sosio-emosional pada diri remaja tersebut.

\section{Media Sosial}

Media sosial secara garis besar diartikan sebagai media online berbasis internet yang dapat diakses oleh para penggunanya (user) untuk berbagi, berpartisipasi dan menciptakan suatu konten baru seperti blog, wiki, forum, jejaring sosial maupun ruang dunia virtual yang didukung melalui teknologi multimedia yang sulit untuk dipisahkan satu sama lain. Media sosial lebih merujuk kepada jenis saluran komunikasi dalam sebuah ikatan, yang mana membolehkan para penggunanya untuk berinteraksi dengan mudah secara bebas, berkongsi dan membicarakan sesuatu dengan menggunakan berbagai elemenelemen multimedia yang terdiri dari teks, gambar, video dan audio. Adapun menurut Kaplan dan Haenlein, 2010 mengungkapkan bahwa "social media is a new form of communication and consists of a variety of commutation tolls such as, blogs, collaborative projects, social networking sites, content communities and virtual world".

Berdasarkan definisi di atas, maka media sosial sebagai media melalui internet yang dapat diindra dan diakses oleh para penggunanya dalam merepresentasikan dirinya, serta memiliki berbagai fungsi sebagai perantara, sarana atau alat untuk berkomunikasi, berinteraksi, bekerja 
sama dan berbagi informasi kepada individu lain. Bahkan dengan adanya media sosial ini akan menciptakan suatu konten berupa jejaring sosial serta terciptanya suatu hubungan yang kuat antar penggunanya dalam sebuah ikatan sosial secara virtual melalui teknologi multimedia.

\section{Etika Pergaulan Antar Lawan Jenis}

Menurut Amin, etika sebagai suatu ilmu yang menjelaskan baik dan buruk, merenungkan, memiliki tujuan yang jelas bagi manusia dalam melakukan perbuatan yang seharusnya dilakukan dan menunjukkan individu ke arah yang lebih baik. Sedangkan, pergaulan dalam psikologi sosial lebih dikenal dengan istilah interaksi sosial. Interaksi sosial diartikan sebagai hubungan antara individu satu dengan individu yang lain, di mana individu dalam berinteraksi saling mempengaruhi satu sama lain atau dengan kata lain ada hubungan timbal balik antar individu lain. Sedangkan, menurut Idi pergaulan adalah kontak langsung antara pendidik dengan anak didik. Dalam hal ini pergaulan meliputi tingkah laku individu yang berinteraksi satu sama lain dalam jangka waktu tertentu. Pergaulan tersebut akan terjadi interaksi sosial di mana interaksi sosial tersebut berasal dari kehidupan sosial, sehingga tanpa interaksi sosial dengan lingkungan di sekitarnya, maka tidak akan ada kehidupan bersama. Sedangkan, lawan jenis diartikan sebagai lawan dari jenis kelamin.
Berdasarkan paparan di atas, maka dapat diketahui bahwa etika pergaulan antar lawan jenis merupakan suatu aturan atau tata nilai mengenai baik dan buruknya perilaku laku manusia dalam melakukan hubungan interaksi sosial dengan lingkungan di sekitarnya yang diwujudkan dengan adanya kontak, hubungan atau komunikasi dengan lawan jenis yang dilakukan secara langsung maupun tidak langsung untuk mencapai tujuan yang baik serta tetap berlandasan pada Al-Qur'an dan Hadits.

\section{METODE PENELITIAN}

Jenis penelitian yang digunakan oleh peneliti berupa penelitian korelasional dengan pendekatan mixed methods. Adapun sampel yang digunakan oleh peneliti yakni purposive sampling, karena pengambilan anggota sampel dari populasi ini berdasarkan pada pertimbangan peneliti sendiri untuk dijadikan sampel. Sedangkan metode pengumpalan data, peneliti menggunakan angket, observasi, wawancara dan dokumentasi. Selanjutnya, data dari hasil penelitian di lapangan akan dilakukan analisis data dengan melalui perhitungan statistik deskriptif dan regresi sederhana melalui bantuan SPSS for windows versi 20.00 .

\section{HASIL DAN PEMBAHASAN Penggunaan Media Sosial}

Aspek dalam penggunaan media sosial ini meliputi media sosial yang 
dimiliki, media sosial yang paling sering digunakan, durasi penggunaan media sosial dalam sehari, tujuan memakai media sosial, informasi yang sering diakses dan dishare di media sosial. Untuk lebih jelasnya dapat dilihat dari hasil analisis berikut ini.

1. Media sosial yang dimiliki dan Media Sosial yang sering digunakan Remaja Islam Tamantirto Utara sebagian besar memiliki Whatsapp 79,17\%, Instagram 69,17\%, Facebook 45\%, Line 24,17\%, Youtube 17,5\%, Bbm 14,17\%, Google 9,17\%, Snapchat 5,83\%, Kakaotalk 4,17\%, Tiktok dan Wordpad 3,33\%, Link in 2,5\%, Gmail dan Twitter 1,67\%, serta Edmodo, Email dan Quipper $0,83 \%$. Mereka memiliki media sosial dengan berbagai aneka bentuk dan jenis media sosial yang diperlukan sesuai dengan kebutuhan dan keperluan mereka masing-masing. Adapun media sosial yang sering digunakan remaja Islam dalam sehari, yakni whatsapp 80,83\%. Instagram 50\%, Facebook 22,5\%, Line 13,33\%, Google 8,33\%, Youtube 4,17\%, serta BBM, Blog dan Chat Messenger memiliki presentase yang sama sebesar 3,33\%. Begitu juga dengan media sosial Tiktok dan Twitter sama-sama memiliki presentase sebesar $0,83 \%$.

2. Durasi penggunaan media sosial dalam sehari dan Tujuan menggunakan media sosial
Remaja Islam di Tamantirto Utara sebagian besar menggunakan media sosial dengan durasi 1-3 jam dalam sehari yakni sebesar $35,83 \%$. Selanjutnya remaja Islam menggunakan media sosial lebih dari 5 jam sebesar 19,17\%, antara 3 sampai 5 jam sebanyak 23,33\%, $16,67 \%$ antara 30 menit sampai 1 jam dan baru di saat waktu luang sekitar 5\% saja. Mereka menggunakan dan mengakses media sosial ini dengan tujuan untuk mengetahui informasi penting sebesar $56,67 \%$. Sedangkan, $42,5 \%$ digunakan untuk berkomunikasi dengan teman, sahabat, orang tua, kerabat, saudara, guru, dosen dan sebagainya. $24,17 \%$ terkait pendidikan biasanya digunakan untuk menerjemahkan ke dalam bahasa Indonesia melalui google translate, belajar bahasa Asing dan sebagainya. Adapun untuk hiburan sebesar $17,5 \%$ dan digunakan untuk menonton film, video, mendengarkan musik, bermain game dan sebagainya. Adapun untuk mengisi waktu luang sebesar $12,5 \%$, bersosialisasi $6,7 \%$, media iklan/bisnis $4,17 \%$, mencari teman spesial dan belanja online memiliki kesamaan presentasenya yakni $3,33 \%$.

3. Informasi yang sering diakses dan dishare di media sosial

Remaja Islam Tamantirto Utara lebih banyak mengakses media sosial untuk masalah pendidikan $45,83 \%$, berita $45 \%$, keagamaan $14,17 \%$, hiburan $27,5 \%$ informasi 
penting $11,76 \%$, Kesehatan/olahraga $10 \%$, Bisnis dan kuliner 4,17\%, Teknologi 3,33\% Biografi tokoh dan hobby $2,5 \%$, dan $1,67 \%$ digunakan untuk mengakses apa saja, tidak ada yang diakses, artikel, tutorial, lifestyle dan online shop. Sedangkan 0,83\% digunakan untuk mengakses otomotif. Adapun mengenai informasi yang sering dishare remaja Islam di media sosial adalahpendidikan $30 \%$, foto $22,5 \%$, informasi berita terkini sebanyak $18,33 \%$, hiburan $17,5 \%$, status $14,17 \%$, agama $12,5 \%$, kesehatan/olahraga dan tidak ada memiliki presentase sama yakni $10 \%$, informasi penting $7,5 \%$, promo barang/bisnis $5,83 \%$, kuliner 3,33\% dan travelling 2,5\%.

\section{Etika Pergaulan Antar Lawan Jenis}

Dalam variabel etika pergaulan antar lawan jenis ini ada lima aspek antara lain bergaul semata-mata karena Allah Swt, menutup aurat, menjaga kemaluan, menundukkan pandangan dan saling bertanggung jawab. Adapun mengenai etika pergaulan antar lawan jenis secara keseluruhan adalah berikut ini: $44,17 \%$ remaja Islam pergaulan dengan lawan jenis tinggi. 26,67\% remaja Islam merasa cukup bergaul dengan lawan jenis dan 13,33\% remaja Islam merasa sangat tinggi untuk bergaul dengan lawan jenis. Bahkan, $12,5 \%$ dan 3,33\% remaja Islam rendah maupun sangat rendah dalam bergaul dengan lawan jenis. Dengan demikian bahwa remaja Islam Tamantirto utara ketika bergaul dengan lawan jenis tergolong tinggi, sebab remaja Islam Tamantirto Utara masih belum bisa menanamkan dan menerapkan etika atau tata cara bergaul dengan lawan jenis di mana pun berada, baik itu itu di lingkungan sekitar, masyarakat, sekolah maupun di kegiatan organisasi ataupun komunitas yang diikuti oleh remaja tersebut.

Islam mengajarkan kepada setiap laki-laki maupun perempuan untuk selalu menjaga kemaluan dan menundukkan pandangan dengan lawan jenis, agar terhindar dari fitnah seksual mata. Bahkan secara psikologis pandangan mata dengan lawan jenis dapat menimbulkan dorongan seksual secara terus-menerus dan menuntut untuk dipenuhi. Maka dari itu, perlu dipahamkan atau dijelaskan mengenai pengertian manfaat menjaga kemaluan dan menundukkan pandangan serta bahaya apabila mengumbar kemaluan maupun pandangan ke lawan jenis. Menjaga pandangan di sini memiliki dua pengertian; Pertama, pandangan lahirartinya melihat dan menikmati bagian tubuh yang menarik dan menggairahkan nafsu birahi. Kedua, pandangan batin yaitu syahwat yang timbul dari hati setelah melihat aurat lawan jenis, sehingga akan menimbulkan perbuatan zina atau hubungan seksual di luar aturan agama maupun norma susila.Mengenai menjaga kemaluan dan menundukkan 
pandangan, Allah Swt sudah menjelaskan di dalam surah An-Nur ayat 30-31 yang artinya "Katakanlah kepada laki-laki yang beriman agar mereka menjaga pandangannya, dan memelihara kemaluannya.... Dan katakanlah kepada perempuan yang beriman agar mereka menjaga pandangannya, dan memelihara kemaluannya....."

Bahkan Rasulullah Saw, juga menerangkan bahwa: "Ada tiga kelompok manusia yang tidak akan melihat api neraka, yaitu orang-orang yang matanya terjaga di jalan Allah, orang yang matanya menangis karena takut kepada Allah, dan orang-orang yang matanya tidak mau melihat halhal yang diharamkan Allah (HR. Thabrani)". Oleh karena itu, setiap laki-laki maupun perempuan yang beriman untuk selalu menjaga kemaluan dan pandangannya dari lawan jenis di mana pun berada. Supaya tidak menimbulkan fitnah dan zina yang sangat dilarang oleh Allah Swt.

\section{Pengaruh Penggunaan Media Sosial Terhadap Etika Pergaulan Antar Lawan Jenis di Kalangan Remaja Islam}

Dari hasil regresi sederhana menggunakan SPSS for windows versi 20.00, maka dapat diketahui bahwa besaran pengaruh variabel independen terhadap variabel dependen dapat dilihat pada nilai $\mathrm{R}$ Square yakni sebesar 0,065. Berarti pengaruh penggunaan media sosial terhadap etika pergaulan antar lawan jenis adalah sebesar $6,5 \%$ dan $93,5 \%$ sisanya dipengaruhi oleh faktor lain yang tidak diteliti oleh peneliti sendiri. Sedangkan, nilai signifikan sebesar 0,005 . Berarti $0,005<0,05$, maka ada pengaruh yang signifikan antara penggunaan media sosial terhadap etika pergaulan antar lawan jenis di kalangan remaja Islam Tamantirto Utara. Dengan demikian, hubungan penggunaan media sosial dengan etika pergaulan antar lawan jenis sebagai hubungan sebab akibat. Artinya apabila penggunaan media sosial tinggi atau baik, maka etika pergaulan antar lawan jenis akan tinggi atau baik juga. Begitu juga sebaliknya, apabila penggunaan media sosial rendah atau kurang baik, maka etika pergaulan antar lawan jenis akan rendah atau kurang baik juga.

\section{KESIMPULAN}

Berdasarkan hasil penelitian yang dilakukan, maka dapat disimpulkan bahwa:

1. Penggunaan media sosial remaja Islam Tamantirto Utara memiliki berbagai variasi dan sesuai kebutuhan masing-masing individu.

2. Etika pergaulan antar lawan jenis remaja Islam di Tamantirto Utara dikategorikan tinggi artinya remaja Islam dalam bergaul dengan lawan jenis masih kurang menerapkan etika atau tata cara pergaulan ketika mereka sedang berinteraksi, berkomunikasi dan berkumpul dengan lawan jenis. 
3. Pengaruh penggunaan media sosial terhadap etika pergaulan antar lawan jenis di kalangan remaja Islam Tamantirto Utara sebesar 6,5\% dan 93,5\% sisanya dipengaruhi oleh faktor lain yang tidak diteliti oleh peneliti sendiri. Sedangkan, nilai signifikan dari hasil analisis regresi sebesar 0,005 .

\section{DAFTAR PUSTAKA}

Ali, Murad dkk. "Strengthening the Academic Usage of Social Media: an Exploratory Study". Journal of King Saud University-Computer and Information Sciences (2017) 29. https://bit.ly/2pX01bL. Diakses hari jum'at, 8 Desember 2017 pada pukul 10.55 .

Amin, Achmad. 1995. Etika. Jakarta: Bulan Bintang.

Bantanie El-, Muhammad Syafi'ie. 2013. Wanita Dambaan Surga. Jakarta: Elex Media Komputindo.

Bungin, Burhan. 2006. Sosiologi Komunikasi. Jakarta: Kencana.

Desmita. 2015. Psikologi Perkembangan. Bandung: Rosda.

Haryanto. "Pemanfataan Media Sosial Sebagai Media Komunikasi Komunitas Pustakawan Homogen dalam Rangka Pemanfaatan Bersama Koleksi Antar Perguruan Tinggi”. Jurnal EduLib. Tahun 5. Volume 5 No. 1. Mei 2015. ISSN: 2089-6549. hlm. 85. http://bit.ly/2ER7b6n.
Diakses hari Sabtu, 4 November 2017 pada pukul 13.19.

Hurlock, Elizabeth B. 1980. Psikologi Perkembangan; Suatu Pendekatan Sepanjang Rentang Kehidupan. Jakarta: Erlangga.

Idi, Abdullah. 2014. Sosiologi Pendidikan; Individu, Masyarakat, dan Pendidikan. Jakarta: Rajawali Pers.

Kementerian Agama RI. Al-Qur'an dan Terjemahannya.

Kementerian Kesehatan RI. "Pusat Data dan Informasi Kementerian Kesehatan RI; Situasi Kesehatan Reproduksi Remaja".ISSN 2442-7659.

http://www.depkes.go.id.

Diakses hari Rabu, 12 Juli 2017 pada pukul 09.57.

Kementerian Perdagangan RI. 2014. Panduan Optimalisasi Media Sosial untuk Kementerian Perdagangan RI. Jakarta: Kemendag.

Papalia, Diane E. 2008. Psikologi Perkembangan Edisi Kesembilan Cetakan Kesatu. terj. A. K. Anwar. (penj.). Jakarta: Kencana.

Risnawati, Indah. 2016. "Perilaku Seksual Pranikah pada Remaja". Jurnal ISSN 2407-9189. Kudus: STIKES Muhammadiyah. https://bit.ly/2G9P1SK. Diakses hari Kamis, 13Juli 2017 pada pukul 09.43.

Santrock, John W. 2007. Remaja Edisi Kesebelas. Jakarta: Erlangga. 
Smetana, Judith G. "Adolescent

Development In Interpersonal and Societal Contexts". Annu. Rev. Psychol. 2006. 57:255-284. http://bit.ly/2BbEqz0. Diakses hari selasa, 5 Desember 2017 pada pukul 08.37.

Sugiyono. 2013. Metode Penelitian Kuantitatif, Kualitatif dan R \& D. Bandung: Alfabeta.
Walgito, Bimo. 2003. Psikologi Sosial (Suatu Pengantar) Edisi Revisi. Yogyakarta: Andi.

Warga KKM. 2016. Tata Etika Penggunaan Media Sosial. Kompleks E, Putrajaya: Kementerian Kesehatan Malaysia. 